\section{Correspondence on 'Long-term outcome of a randomised controlled trial comparing tacrolimus with mycophenolate mofetil as induction therapy for active lupus nephritis'}

I read with great interest the recently published long-term outcome of a randomised controlled trial comparing tacrolimus with mycophenolate mofetil as induction therapy for active lupus nephritis. ${ }^{1}$ Emerging evidence showed the efficacy of calcineurin inhibitors (CNIs) in patients with lupus nephritis, including ciclosporin A, tacrolimus and voclosporin. ${ }^{1-5}$ However, I am concerned about the risks of thrombotic microangiopathy (TMA) and posterior reversible encephalopathy syndrome (PRES) when CNIs were given for patients with systemic lupus erythematosus (SLE) with concomitant antiphospholipid syndrome (APS). The anticardiolipin or lupus anticoagulant was present in 48 out of 150 patients $(28 \%)$ in the study by Mok et $a l^{3}$ which was not reported in other studies. ${ }^{245}$ There were about $17.6 \%$ patients with TMA in a cohort of 341 patients with stable lupus nephritis, who had the poorest renal outcome. ${ }^{6}$ The use of CNIs in patients with SLE/APS should be prudent because both CNI and APS are risk factors for the occurrence of TMA, ${ }^{7}$ especially for whom with the presence of histological features of TMA. PRES is contributed by endothelial cell dysfunction. SLE/APS, renal impairment and CNIs are known risk factors for PRES. ${ }^{8}$ There were 4 out of 177 cases reported PRES in the voclosporin group regardless of the dosage, whereas none in the placebo group from the Aurinia Urinary Protein Reduction Active Lupus With Voclosporin (AURA-LV) study. ${ }^{4}$ I also noted one case developed epilepsy in the group of multitarget therapy, but none in the group of cyclophosphamide from the study by Liu et al. ${ }^{2}$ The use of CNIs in patients with SLE/APS may confer a higher risk of PRES. In summary, the risks of TMA and PRES should not be neglected when CNIs are used for patient with SLE/APS. The authors should be encouraged to report the outcomes of CNIs use in patients with SLE and APS, which would shed light on the management of these patients.

\section{Chuanhui Xu $\odot$}

Correspondence to Dr Chuanhui Xu, Department of Rheumatology, Allergy and Immunology, Tan Tock Seng Hospital, Singapore 308433, Singapore; xuchuanhui2008@gmail.com

Contributors CX conceptualise and write up the manuscript.
Funding The authors have not declared a specific grant for this research from any funding agency in the public, commercial or not-for-profit sectors.

Competing interests None declared.

Patient and public involvement Patients and/or the public were not involved in the design, or conduct, or reporting, or dissemination plans of this research.

Patient consent for publication Not required.

Provenance and peer review Not commissioned; internally peer reviewed.

(c) Author(s) (or their employer(s)) 2020. No commercial re-use. See rights and permissions. Published by BMJ.

\section{Check for updates}

To cite Xu C. Ann Rheum Dis Epub ahead of print: [please include Day Month Year]. doi:10.1136/annrheumdis-2020-219056

Received 7 September 2020

Accepted 9 September 2020

\section{SLinked}

http://dx.doi.org/10.1136/annrheumdis-2020-219056

Ann Rheum Dis 2020;0:1. doi:10.1136/annrheumdis-2020-219056

ORCID iD

Chuanhui Xu http://orcid.org/0000-0002-3222-7168

\section{REFERENCES}

1 Mok CC, Ho LY, Ying SKY, et al. Long-Term outcome of a randomised controlled trial comparing tacrolimus with mycophenolate mofetil as induction therapy for active lupus nephritis. Ann Rheum Dis 2020;79:1070-6.

2 Liu Z, Zhang H, Liu Z, et al. Multitarget therapy for induction treatment of lupus nephritis: a randomized trial. Ann Intern Med 2015;162:18-26.

3 Mok CC, Ying KY, Yim CW, et al. Tacrolimus versus mycophenolate mofetil for induction therapy of lupus nephritis: a randomised controlled trial and long-term follow-up. Ann Rheum Dis 2016;75:30-6.

4 Rovin BH, Solomons N, Pendergraft WF, et al. A randomized, controlled double-blind study comparing the efficacy and safety of dose-ranging voclosporin with placebo in achieving remission in patients with active lupus nephritis. Kidney Int 2019;95:219-31.

5 Zavada J, Pešickova S, Ryšava R, et al. Cyclosporine A or intravenous cyclophosphamide for lupus nephritis: the Cyclofa-Lune study. Lupus 2010;19:1281-9.

$6 \mathrm{Wu}$ L-H, Yu F, Tan Y, et al. Inclusion of renal vascular lesions in the 2003 ISN/RPS system for classifying lupus nephritis improves renal outcome predictions. Kidney Int 2013;83:715-23.

7 Kotzen ES, Roy S, Jain K. Antiphospholipid syndrome nephropathy and other thrombotic microangiopathies among patients with systemic lupus erythematosus. Adv Chronic Kidney Dis 2019;26:376-86.

8 Fugate JE, Rabinstein AA. Posterior reversible encephalopathy syndrome: clinical and radiological manifestations, pathophysiology, and outstanding questions. Lancet Neurol 2015;14:914-25. 